\title{
Coffee Cherries Drying Trials Utilizing the Hybrid Solar Dryer
}

\author{
Y. Yuwana ${ }^{1 *}$, E.N. Silvia ${ }^{1}$, B. Sidebang ${ }^{1}$ \\ ${ }^{1}$ Agricultural Technology Department, Faculty of Agriculture, University of Bengkulu, Indonesia \\ * Corresponding author (email address: yuwana@unib.ac.id)
}

\begin{abstract}
Drying process of coffee cherries by sun drying needs two-three weeks to produce dry coffee beans. Efforts have been made by researchers to accelerate this process by introducing various types of solar dryer but their drying performances are subject to be improved. This experimental study aimed to explore the performance of an uniquely designed hybrid solar dryer for coffee cherry drying. Special characteristic of the dryer is electricity independence that makes it possible to be installed wherever demanded. Two experiments were set up in which the dryer was operated by solar energy accompanied with sun drying as a comparison and by the biomass energy generated from wood combustion. Four overlay thicknesses of coffee cherry samples were prepared together with samples for sun drying as comparison for the first experiment and three overlay thicknesses of coffee cherry samples were provided for the second experiment. The result of the first experiment indicated that the curves of coffee cherry moisture content plotted against drying time were linear and the time spends to complete the drying process for the overlay thickness of 4, 8, 12 and $16 \mathrm{~cm}$ were 91.42 $\mathrm{h}, 103,93 \mathrm{~h}, 109,65 \mathrm{~h}$ and $138,75 \mathrm{~h}$ respectively which were faster than those of sun drying about $56.04 \mathrm{~h}$, $29,22 \mathrm{~h}, 24,28 \mathrm{~h}$ and $21,98 \mathrm{~h}$ respectively. The result of the second experiment demonstrated that utilizing wood fuel supply of $5 \mathrm{~kg}$ per hour, the curves of coffee cherry moisture content plotted against drying time were quadratic and the time spends to finish drying process for the overlay thickness of 5,10 and $15 \mathrm{~cm}$ were $61.12 \mathrm{~h}, 76.23 \mathrm{~h}$ and $89.37 \mathrm{~h}$, respectively. The fuel consumption to complete drying for the overlay thickness of 5,10 and $15 \mathrm{~cm}$ were $0.53,0.33$ and $0.26 \mathrm{~kg}$ of wood per $\mathrm{kg}$ of fresh coffee cherries respectively. It is concluded that the hybrid solar dryer being tested was able to significantly accelerate the drying process of coffee cherries.
\end{abstract}

Keywords: Hybrid dryer, coffee, solar energy, fuel combustion energy, overlay thickness

\section{INTRODUCTION}

Drying is the most common way to preserve or process agricultural products in the tropics, including coffee. Sun drying is a traditional drying method that is widely practiced in developing countries including Indonesia. This typical drying is carried out by placing the product under direct sunlight whose performance is determined by the position of the sun and weather conditions. It is usually done by laying the product on cement floors, mats, soil surfaces, asphalt road surfaces, and other surfaces [1]. Sun drying is very practical but requires a large area [2], often at risk of loss of product quality and materials due to microorganisms, insects, pests, animals, dust, dirt, and rain [3] [4]. To overcome this problem, solar dryers are developed and based on how the solar energy is manipulated they may be categorized into direct mode [5] [6] [7] [8], indirect mode [6] [9] [10] [11] and mixed mode [3] [12] [13]. The direct model solar dryer works similar to sun drying but the product is shaded with translucent material, such as certain glass or plastic, and water is transferred from the product through its upper surface. In an indirect type dryer, the drying air is heated by a collector which collects heat from the sun and the water contained by the product is evaporated by the heated drying air. Furthermore, the working principle of a mixed model solar dryer is a combination of a direct model and an indirect model, i.e. the wet product being dried receives direct energy from the sun and hot air supplied by the collector.

Even though some have been equipped with heat storage devices, solar dryers still face obstacles, especially during the rainy season and prolonged bad weather, because the energy source utilized is only from the sun. To overcome these obstacles, hybrid solar dryers are developed and various models have been explored. Hybrid solar dryers are dryers that work with the solar energy and other energies, such as electric energy [14] [15] [16] and biomass energy [17] [[18] [19] [20]. In a hybrid dryer, the energy supplied into the drying chamber to carry out the drying process may come directly from the sun, from a 
heat collector, electric heater, heat exchanger that delivers heat from the furnace. The majority of hybrid dryers are highly dependent on electrical energy, both for the substitution of drying energy [21] [22] [23] [24] and for circulating drying air [25] [26]. This is a problem for regions where electricity supply is still limited or remote areas.

In the dry coffee processing, the harvested coffee cherris are dried directly into dried coffee logs which are still protected by the dry pulp layer. The dry coffee cherries have a water content of $12.5 \%$ corresponding to the water content of coffee beans recommended by INS (Indonesian National Standard) 01-2907-1992 which is 12$13 \%$ (wet basis). If the drying is done with sun drying, it takes 2-3 weeks of drying time. This long period of sun drying is suspected to be the cause of the inferior quality of coffee beans produced by the coffee farmers. Efforts have been done to shorten the drying period of coffee by introducing solar energy driers [27] [28] and hybrid dryers [29] [30]. Widyotomo [28] introduced a solar energy dryer in the form of a translucent building and tested its performance to dry coffee cherries with a thickness of 30 , 60 and $90 \mathrm{~kg} \mathrm{~m}^{-2}$. He found that the maximum temperature of the dryer was $52^{\circ} \mathrm{C}$ and the dryer reduced the water content of the coffee cherries from $58-64 \%$ to $12 \%$ for 180-336 hours. Agustina et al. [30] designed a hybrid solar dryer with the supplement energy supply from rice husk biomass combustion for coffee drying, comprising of a drying chamber measuring $93 \mathrm{~cm} \times 93 \mathrm{~cm} \times 29 \mathrm{~cm}$ equipped with two solar heat collectors, a furnace, heat exchanger pipes, blowers and turbine ventilators. Experimenting for Arabica coffee beans with a stack thickness of $30 \mathrm{~cm}$, the dryer generated the maximum drying temperature of $53-55^{\circ} \mathrm{C}$ and decreased the coffee's water content from $48.7 \%$ to $11.40 \%$ within 2 days.
The purpose of this study was to investigate the performance of the dryer when operated without load using solar energy and biomass combustion heat, and when operated with these two types of energy sources to dry cherry coffee, looking forward to improving the coffee drying performance.

\section{MATERIALS AND METHODS}

\subsection{Materials}

The coffee cherries used in the experiments were picked selectively in a local coffee plantation situated at $500 \mathrm{~m}$ above the sea level in Rejang Lebong District, a day before the experiments. The charry samples were placed in the plastic bags to be transported to the experiment location, the Laboratory of Agricultural Technology, Faculty of Agriculture, University of Bengkulu where the hybrid solar dryer was installed. The plastic bags filled with coffee cherries were opened and then stored in room temperatures until utilized for the experiments. The measured bulk density of fresh coffee cherries was 607 $\mathrm{kg} . \mathrm{m}^{-3}$

Dry rubber wood (Hevea brasiliensis) having a diameter ranging 10 to $20 \mathrm{~cm}$, taken from the rejuvenation plants was used as a fuel source when the dryer was operated with fuel combustion heat. The wood was chopped in $1 \mathrm{~m}$ length in order to be smoothly supplied into the furnace.

\subsection{Methods}

The hybrid dryer solar dryer used in the experiment is presented in Figure 1.

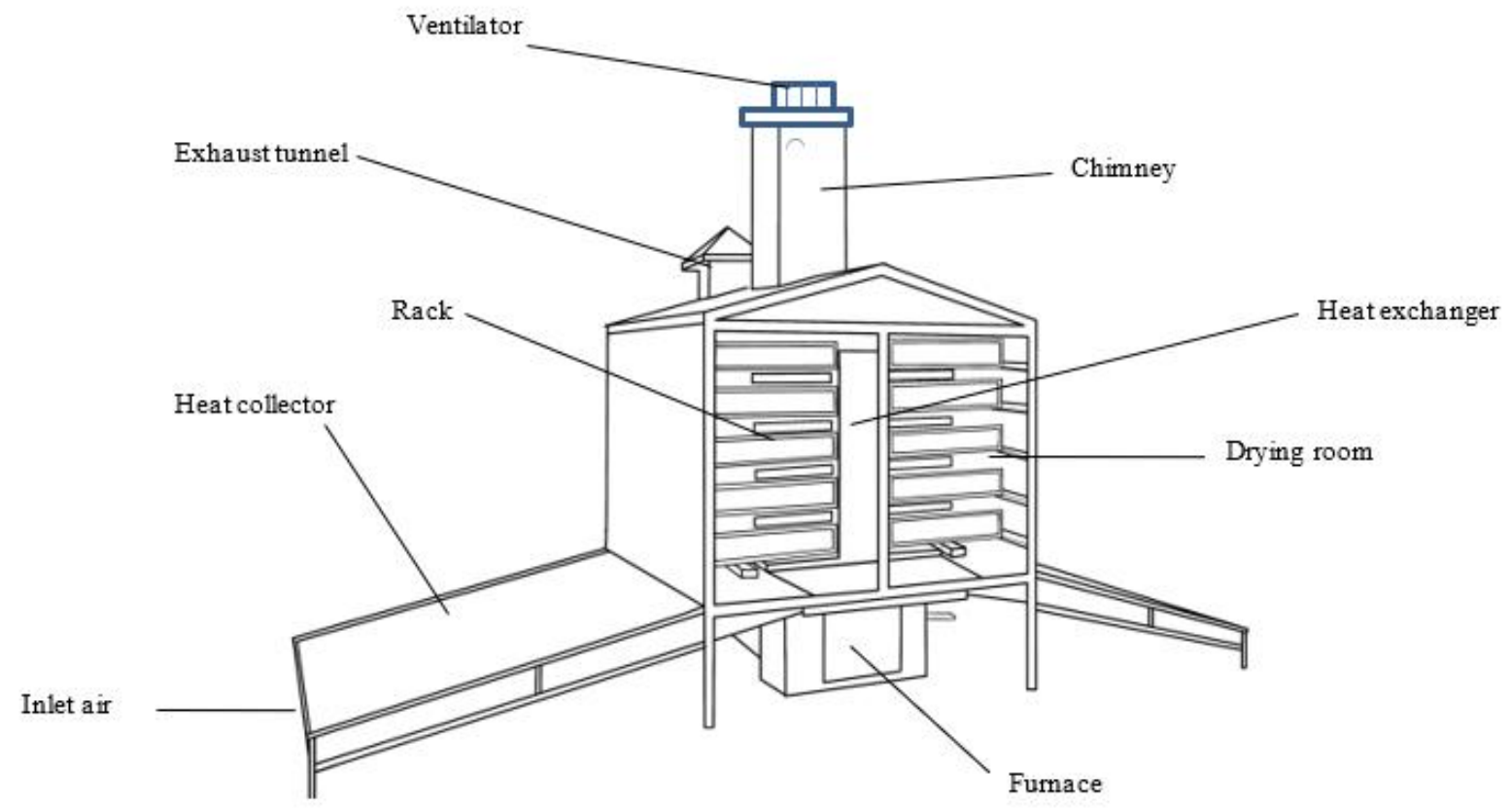

Figure 1. Hybrid solar dryer 
The main structure of the dryer is made from a light weight steel frame, walled and roofed with transparent glass. The dryer consists of a drying room, furnace, heat exchanger, chimney, and heat collector. The drying room contains a heat exchanger integrated with the furnace at the bottom, 10 drying racks (right 5 shelves, left 5 shelves), and a door for removing the dried material. The heat exchanger is composed of the body and 80 hollow fish shaped bone fins arranged in 4 levels (right 40 fins, left 40 fins) made of steel plates, and filled with water as heat storage.

The base of the heat exchanger bordering the furnace is made of thick high hot absorbent steel that supports a hollow wing that is joined to the body of the heat exchanger. The furnace is equipped with a fuel intake door at the front, 16 oxygen supply holes in the wall (right 8, left 8) and an exhaust gas channel at the rear. The base and wall of the furnace are made of brick coated with mud mixed with cement while the exhaust gas channel is made of cement-bonded brick. Drying racks are located between the heat exchanger fins except the top two racks which are located above the top surface of the heat exchanger fins. Drying rack is made of a lightweight steel frame mounted stainless steel wire mesh (ram wire) which serves to put the coffee cherries to be dried. Chimney is made of a lightweight steel frame and aluminum plate wall, and equipped with a ventilator turbine to improve air circulation and suck moist air from the drying room. The heat collector has a heat absorbing surface in the form of black-painted wave zinc which is placed on top of the heat insulator made of plywood, glass roofed and equipped with an air inlet. This collector serves to trap heat from the sun and supply it to the drying room. The dryer is installed longitudinally toward the sun.

Operating with solar energy, the dryer works as follows. Both the drying room and the heat collector receive heat from the sun and the majority part of the heat penetrates in the heat collector plenum is accumulated by the collector plate that heats the entering air from the inlet. The heat exchanger stores the heat of direct sun lights striking its surface and the heat transferred from the drying air in the drying room. This stored heat will be released back to the drying room when the drying room temperature is lower. The hot air in the drying room has a smaller mass density than the outside air. This condition creates an adequate air pressure gradient between the top point in the chimney and the collector plenum that causes continuous flow of the drying air from the inlet at the lower end of the collector to the outlet at the upper end of the chimney. This flow will be accelerated by the turbine ventilator. This drying air evaporates the water contained by wet coffee cherries placed on the drying racks so that the water content of the coffee cherries decreases to the desired level $(12 \%)$ as an indication that the drying process can be completed.

Working with fuel combustion heat, the drying operation works in the following sequence. The fuel is put into the furnace, then ignited. After the fuel is ignited the furnace door is closed and oxygen supply is provided from the holes at the furnace's wall. The proper supply of oxygen is also facilitated by the exhaust gas channel installed at the back end of the furnace. Combustion heat is transferred to the heat exchanger through its base, stored by the water inside and subsequently delivered to the drying room through the surface of the body's wall and the fins of the heat exchanger. This heat will be carried by the fresh air that enters from the inlet and flows into the chimney, and at the same time the water contained by the wet coffee cherries being dried is evaporated.

The experiments were set up in two series. The first series of experiments was carried out by operating the dryer with solar energy, accompanied by sun drying as comparison, and the second series of experiment the dryer was operated with fuel combustion energy. In the first series of experiments, the coffee cherry samples were placed in the sample box made of anti corrosive ram wire cube of $15 \mathrm{~cm}$ length, $15 \mathrm{~cm}$ width and $15 \mathrm{~cm}$ height. Four different thicknesses of overlay, i.e. 4, 8, 12 and $16 \mathrm{~cm}$ were prepared. For each thickness of overlay, 4 samples were provided, and 3 samples were placed on the drying racks and 1 sample was placed outside the dryer to be dried by sun drying as a control. In the drying room the samples were placed on shelves on floors 1,3 and $5\left(1^{\text {st }}\right.$ floor right, $3^{\text {rd }}$ floor left and $5^{\text {th }}$ floor right) so that on each rack of the corresponding floor, there were samples of 4 thicknesses of overlay. The arrangement of the samples was as follows. The boxes containing the samples were placed in their positions, lined lengthwise in the middle of the shelf and then all the rack area was filled with coffee cherries with a thickness of overlay of $8 \mathrm{~cm}$. The parameters observed in the first series drying test were temperature and humidity of the drying room and ambient air, the velocity of air flow inside the chimney and the sample weight. These parameters were observed from 9.AM to $4 \mathrm{PM}$. The measurement of the drying room temperature and humidity was done by placing five thermohygrometers at each rack level and one thermohygrometer in the shade area outside the dryer. The velocity of air flow in the chimney was measured using an anemometer. Observation of the temperature and humidity of the drying room and ambient air was done at 30 minutes interval while the velocity of air flow the chimney and the sample weight were observed at 60 minutes interval. The drying operation was continued to the next days until the moisture content of the coffee cherry reached less than $12 \%$ wet basis according to the Indonesian National Standard (INS) for coffee beans. The initial and final moisture contents were determined by placing the coffee cherry samples in the oven having temperature $105^{\circ} \mathrm{C}$ for 16 hours (INS for coffee bean)

In the second series of experiment, the cherry samples were prepared in three different thickness overlays, i.e. 5,10 and $15 \mathrm{~cm}$. The dryer was covered with UV-colored (green) plastic to prevent the dryer from receiving additional heat from the sun. The first fuel was loaded and ignited on the fuel platform starting at $8 \mathrm{AM}$. After the fuel was lit, the platform was entered into the furnace, the proper combustion of fuel was maintained by subsequent fuel supplies and the last fuel supply ended at 6 PM. Observation of parameters was carried out from 9 
$\mathrm{AM}$ to $6 \mathrm{AM}$ at the next day. The measurement of parameters and the interval time of the observation were conducted the same manner as the first series of experiments. The total consumption of fuel from the first supply to the final supply was recorded and then the average fuel supply per hour was determined so that the weight of wood required to complete the drying process for each thickness of the overlay, i.e. when the water content of coffee cherry reached $12 \%$, could be found.

\section{RESULTS AND DISCUSSION}

Data of temperature, relative humidity, air flow velocity in the chimney and moisture content of the samples were plotted against drying time. The equation produced by the relationship of moisture content and drying time was used to determine the drying time to complete the drying process. The results of the third series of drying tests are shown in Figure $2-8$.

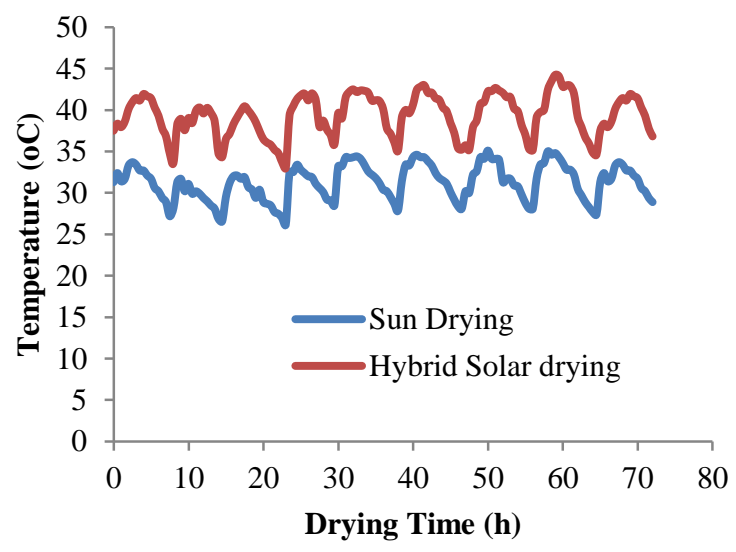

Figure 2. Temperatures of solar drying air and sun drying air when the dryer was operated with solar energy

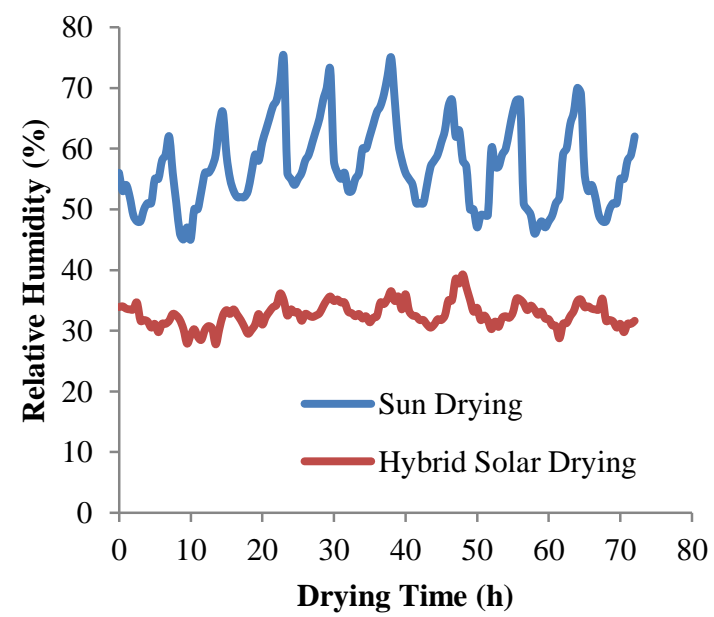

Figure 3. Relative humidity values of solar drying air and sun drying air when the dryer was operated with solar energy

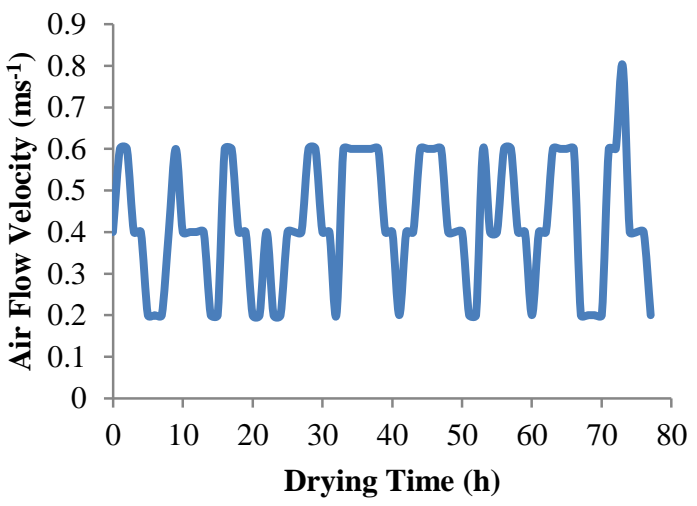

Figure 4. Velocity of chimney air flow when the dryer was operated with solar energy

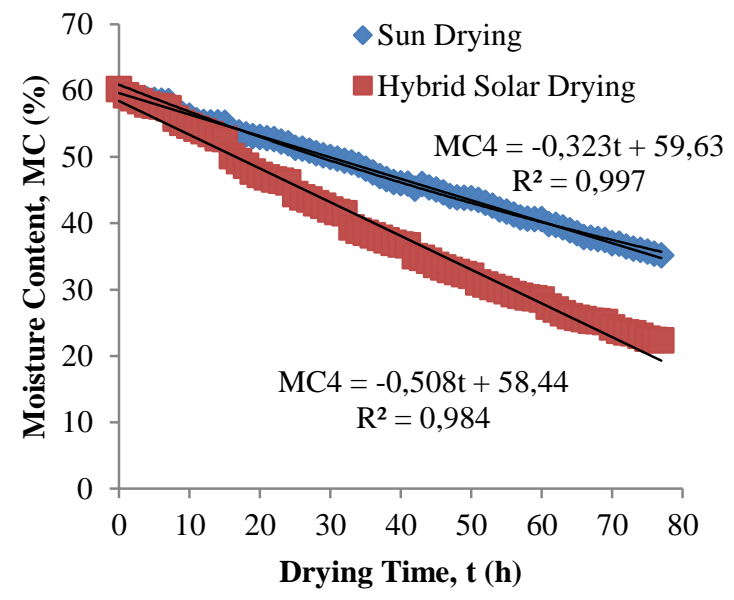

Figure 5. Coffee cherry moisture content plotted against drying time for $4 \mathrm{~cm}$ thickness of overlay when the dryer was operated with solar energy

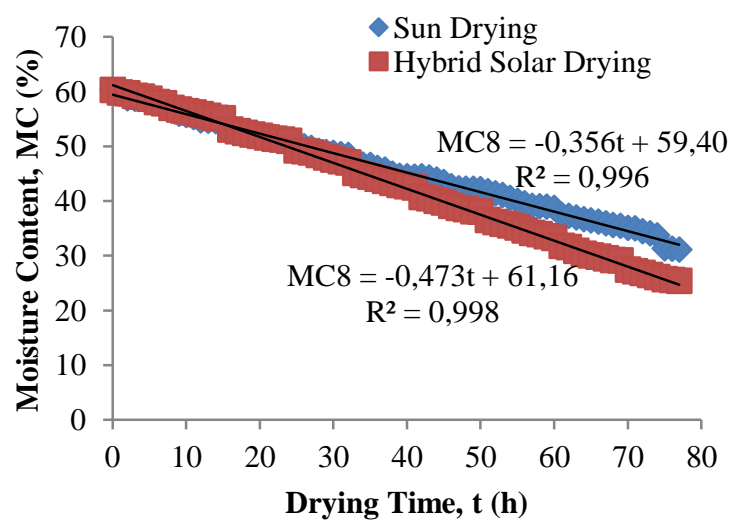


Figure 6. Coffee cherry moisture content plotted against drying time for $8 \mathrm{~cm}$ thickness of overlay when the dryer was operated with solar energy

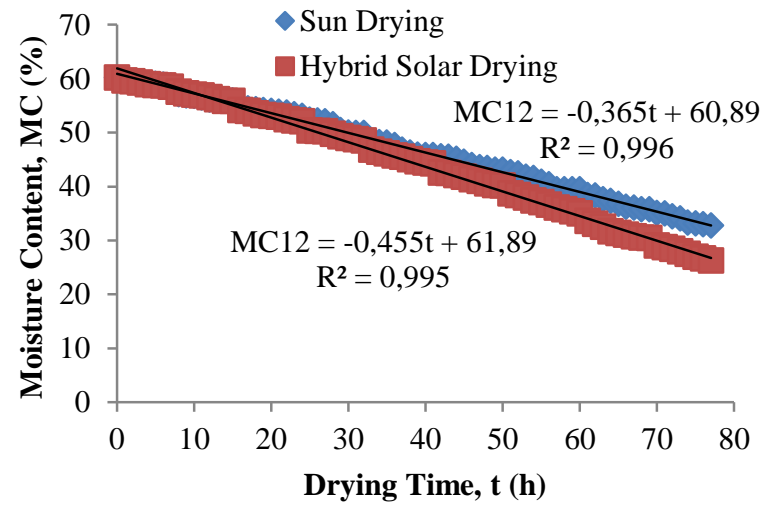

Figure 7. Coffee cherry moisture content plotted against drying time for $12 \mathrm{~cm}$ thickness of overlay when the dryer was operated with solar energy

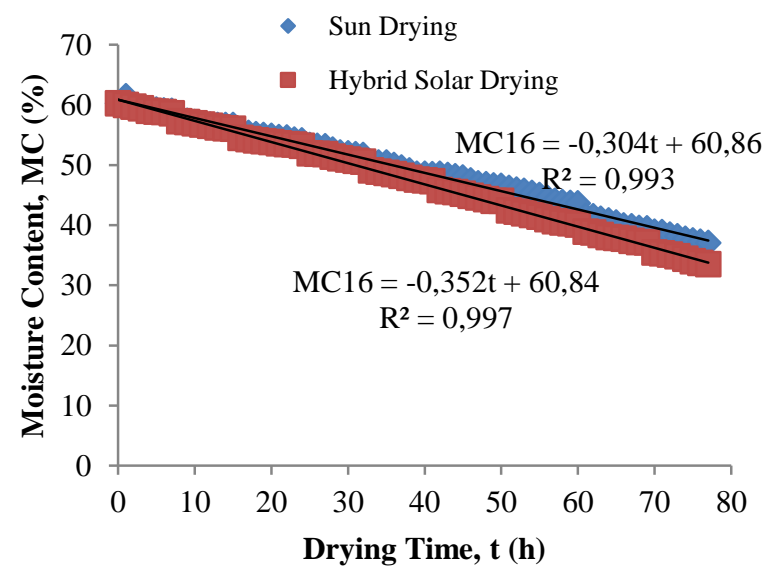

Figure 8 . Coffee cherry moisture content plotted against drying time for $16 \mathrm{~cm}$ thickness of overlay when the dryer was operated with solar.

The drying data shows that the dryer was able to increase the drying room temperature of $8.36^{\circ} \mathrm{C}$ higher than the ambient air temperature and decrease the drying room humidity of $24.33 \%$ lower than the ambient air humidity. The curves of coffee cherry moisture content plotted against drying time were linear for all overlay thicknesses. Furthermore, the time spends to complete the drying process for the overlay thickness of of $4,8,12$ and $16 \mathrm{~cm}$ were $91.42 \mathrm{~h}$ (56.04 $\mathrm{h}$ faster than the sun drying), $103.93 \mathrm{~h}$ (29.22 $\mathrm{h}$ faster than the sun drying), $109.65 \mathrm{~h}(24.28 \mathrm{~h}$ faster than the sun drying), and $138.75 \mathrm{~h}$ (21.98 $\mathrm{h}$ faster than the sun drying). Compared to the results obtained by Widyotomo et al [28] by converting coffee weight per area of 30,60 and $90 \mathrm{~kg} \cdot \mathrm{m}^{2}$ to overlay thickness of 5, 10 and 15 $\mathrm{cm}$ thick with the time spends to complete drying process of 180-336 h, then the time spends for the overlay thickness of 4-16 cm, which were only $91.42-138.75 \mathrm{~h}$, are much faster.

The results of the third series of drying test are demonstrated in Figure 9- 12

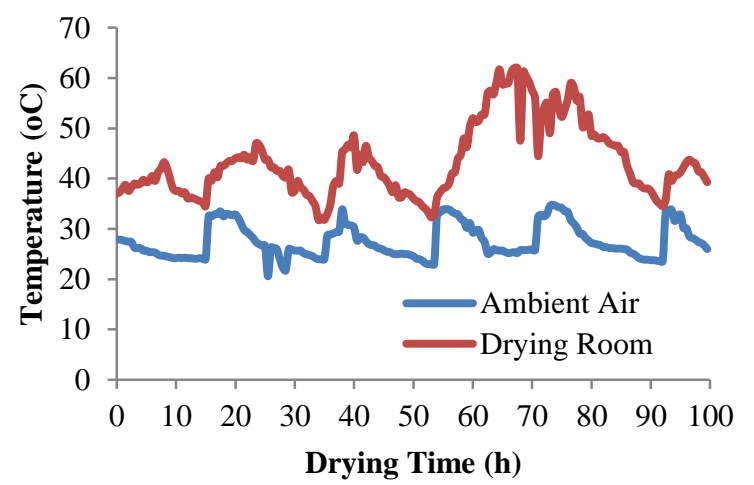

Figure 9. Temperatures of drying room and ambient air when the dryer was operated with biomass combustion energy

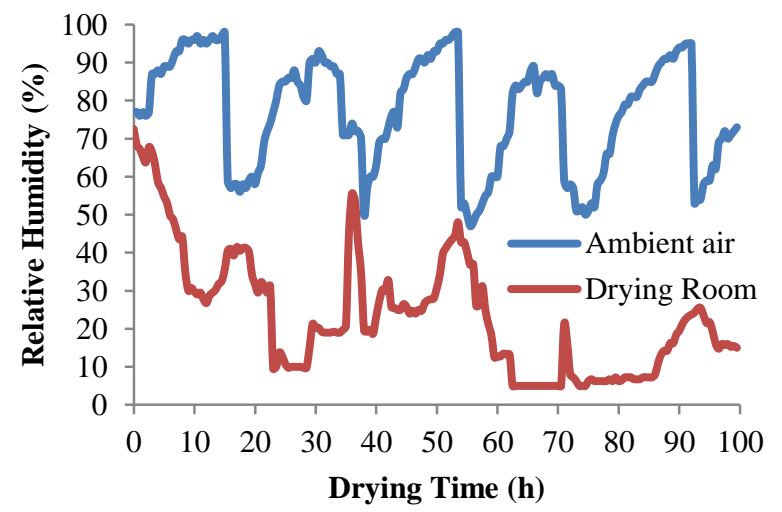

Figure 10. Relative humidity values of drying room and ambient air when the dryer was operated with biomass combustion energy

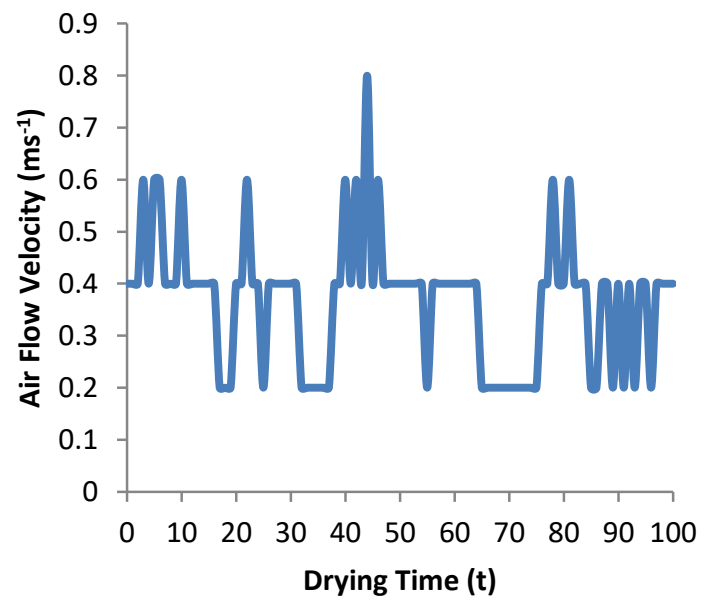


Figure 11. Velocity of chimney air flow when the dryer was operated with biomass combustion energy

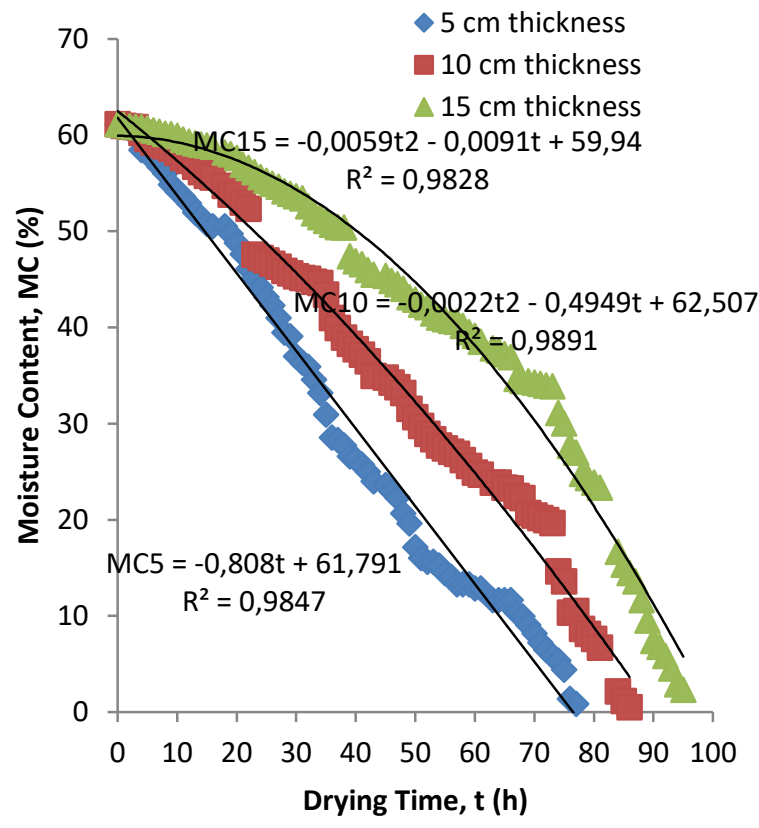

Figure 12. Coffee cherries moisture content plotted against drying time when the dryer was operated with biomass combustion energy

From Figure 9 and 10 can be found that the differences in temperature and humidity of the drying room from the ambient air were $15.82^{\circ} \mathrm{C}$ (higher) and $53.43 \%$ (lower) respectively. The curves of coffee cherries moisture content plotted against drying time were quadratic and the time spent to finish the drying process for the overlay thickness of 5,10 , and $15 \mathrm{~cm}$ were $61.12 \mathrm{~h}$, $76.23 \mathrm{~h}$ and $89.37 \mathrm{~h}$, respectively. Thus, if calculated in the number of days, the time spent to complete the drying process was only 3 to 5 days. In term of fuel consumption, the amount of fuel needed to dry coffee cherries per unit weight was determined as follows. As the above mentioned that the dryer fuel supply was $5 \mathrm{~kg}$ wood per hour. The measured bulk density of fresh coffee cherries was $607 \mathrm{~kg} . \mathrm{m}^{-3}$ so together with the total area of racks, the corresponding weights for the 5,10 and $15 \mathrm{~cm}$ overlay thickness were $577,3 \mathrm{~kg}, 1154,6 \mathrm{~kg}$ and $1731,8 \mathrm{~kg}$ respectively. Using the values of these parameters and the obtained time spents, the amounts of wood to dry coffee cherries for the overlay thickness of 5, 10 and $15 \mathrm{~cm}$ were $0.53,0,33$ and $0,26 \mathrm{~kg}$ wood per $\mathrm{kg}$ fresh coffee cherries respectively. The bigger the overlay thickness was the more economical of fuel consumption.

\section{CONCLUSION}

Operated by solar energy the dryer increased drying room temperature of $8.36^{\circ} \mathrm{C}$ higher than that of ambient air, and decreased drying room relative humidity of $24.33 \%$ lower than that of ambient air. The relationship between coffee cheryy moisture content and drying time was linear and the time spends to complete drying process for overlay thickness $4,8,12$ and $16 \mathrm{~cm}$ were $91.42 \mathrm{~h}$ (56.04 h faster than sun drying), 103, $93 \mathrm{~h}(29.22 \mathrm{~h}$ faster than the sun drying), $109.65 \mathrm{~h}(24.28 \mathrm{~h}$ faster than the sun drying), and $138.75 \mathrm{~h}$ (21.98 $\mathrm{h}$ faster than the sun drying). The coffee cherry drying utilizing wood combustion energy demonstrated that the generated drying room temperature and humidity were $15.82^{\circ} \mathrm{C}$ (higher) and $53.43 \%$ (lower) than those of ambient air. The relationship between coffee cherry moisture content and drying time was quadratic, and the time spent to finish the drying process for the overlay thickness of the 5,10 and $15 \mathrm{~cm}$ were $61.12 \mathrm{~h}, 76.23 \mathrm{~h}$ and $89.37 \mathrm{~h}$ respectively. The fuel consumption to complete drying process for the overlay thickness of 5,10 and $15 \mathrm{~cm}$ were $0.53,0.33$ and $0.26 \mathrm{~kg}$ of wood per $\mathrm{kg}$ of fresh coffee cherries.

\section{ACKNOWLEDGMENT}

This research was financially supported by the Ministry of Education and Culture Republic of Indonesia under the scheme of Applied Research for the Excellence of Higher Education.

\section{REFERENCES}

[1] B.T. Abur, H. Dan-Dakouta, and G. Egbo, 'Food security: Solar dryers and effective food preservation', Int. J. Adv. Engg. Res. Studies, vol. 3, no. 2, pp. 166171,2014

[2] T.B. Prakash and S. Satyanayarana, 'Performance analysis of solar drying system for Guntur Chili', IJLTET., vol. 4, no. 2, pp. 283-298, 2014.

[3] S. Panchal, S.K. Solanki, S.Yadav, A.K. Tilkar, R. Nagaich, 'Design, construction and Testing of solar dryer with roughened surface solar air heater', Int. J. Innov. Res. Eng \& Sci., vol. 7, no. 2, pp. 7-17. 2013.

[4] M.S. Sontakke and S.P. Salve, 'Solar drying technologies: A review', IRJES., vol. 4, no. 4, pp. 2935, 2015.

[5] J.O. Olokor and F.M. Omojowo, 'Adaptation and improvement of a simple solar tent dryer to enhance fish drying', Nature and Science, vol. 7, no. 10, pp. 1824, 2009.

[6] S.S. Nandwani, 'Design construction and study of direct indirect natural circulation solar dryer in Costa Rica', ISIESCO Sci. Tech. Vision, vol. 7, no. 11, pp. 43-47, 2011.

[7] E.A. Almuhanna, 'Utilization of a solar greenhouse as a solar dryer for drying dates under the climatic 
conditions of the Eastern Province of Saudi Arabia', J. Agric. Sci., vol. 4, no. 3, pp. 237-246, 2012.

[8] S. Arun, S. Ayyappan, and V.V. Sreenarayanan, 'Experimental studies on drying characteristics of tomato in a solar tunnel greenhouse dryer', IJRTE., vol. 3, no, 4, pp. 32-37, 2014.

[9] J. Banout and P. Ehl, 'Using a double-pass solar dryer for drying of bamboo shoots', J. Agr. \& Rural Dev. Trop. Subtrop., vol. 111, no. 2, pp. 119-127, 2010.

[10] F. Sulaiman, N. Abdullah, and Z. Aliasak, 'Solar drying system for drying empty bunches', J. Phys.Sci., vol. 24, no. 1, pp. 75-93, 2013.

[11] P.C. Phadke, P.V. Walke, and V.M. Kriplani, 'A review on indirect solar dryers', ARPN J.Eng.Appl.Sci., vol. 10, no. 8, pp. 3360-3371, 2015.

[12] A. Azimi, T. Tavakoli, H.K. Beheshti, and A. Rahimia, 'Experimental study on eggplant drying by an indirect solar dryer and open sun drying', Iranica J. Energy and Environment, vol. 3, no. 4, pp. 348354, 2012.

[13] A. Munir, U. Sultan, and M. Iqbal, 'Development and performance evaluation of a locally fabricated portable solar tunnel dryer for drying of fruits, vegetables and medicinal plants', Pak. J. Agri. Sci., vol. 50, no. 3, 493-498, 2013.

[14] A.G. Ferreira, A.L.T. Charbel, R.L. Pires, J.G. Silva, and C.B. Maia, 'Experimental analysis of a hybrid dryer', Eng Ter., vol. 6, no. 2, pp. 3-7, 2007.

[15] E.C. Rodriguez, I.P. Fiueroa, and C.A.R. Mercado, 'Feasibility analysis of drying process habanero chili using a hybrid-solar-fluidized bed dryer in Yucatan Mexico', J. Energy Power Eng., vol. 7, pp. 18981908, 2013.

[16] A. Reyes, A. Mahn, and V. Cares, 'Analysis of dried onions in a hybrid solar dryer, freeze dryer and tunnel dryer', Chem. Eng. Trans., vol. 43, 2015.

[17] T. Thanaraj, D.A.N. Dharmasena, and U. Samarajeewa, 'Development of rotary solar hybrid dryer for small scale copra processing', Trop. Agr. Res., vol. 16 pp. 305-315, 2004.

[18] K. Gunasekaran, V. Shanmugam, and P. Suresh, 'Modeling and analytical experimental study of hybrid solar dryer integrated with biomass dryer for drying coleus forskohlii stems', IPSSIT., vol. 28, pp. 28-32, 2012.

[19] D. Saravanan, D., V.H. Wilson, and S. Kumarasamy, 'Design and thermal performance of the solar biomass hybrid dryer for cashew drying', Mech. Eng., vol. 12, no. 3, pp. 277-288, 2014.
[20] S. Dhanushkodi, V.H. Wilson, and K. Sudhakar, 'Simulation of solar biomass hybrid dryer for drying cashew kernel', Adv. Appl. Sci. Res., vol. 6, no. 8, pp. 148-154, 2015.

[21] C.B. Maia, A.G. Ferreira, L. Caberas-Gomez, S.M. Hanriot, and T.O. Martin, 'Simulation of the airflow inside a hybrid dryer', IJRRAS., vol. 10, no. 3, pp. 382-389, 2012.

[22] K.G. Sajith and C. Muraleedharan, 'A study on drying of amla using a hybrid dryer', IJIRSET., vol. 2, no. 1, pp. 794-799, 2013.

[23] H. Mortezapour, B. Ghobadian, M.H. Khoshtagaza, and S. Minaei, 'Drying kinetics and quality characteristics of saffron dried with a heat pump assisted hybrid photovoltaic-thermal solar dryer', J.Agr.Sci. Tech., vol. 16, pp. 33-45, 2014.

[24] K.G. Sajith and C. Muraleedharan, 'Economic analysis of hybrid photovoltaic/thermal solar dryer for drying amla', IJERT., vol. 3, no. 8, pp. 907-910, 2014.

[25] S. Dhanuskodi, R. Sukumaran, and H. Wilson, 'Investigation of solar biomass hybrid system for drying cashew', Int. J. Chem. Tech. Res., vol. 5, no. 2, pp. 1076-1082, 2013.

[26] A. Reyes, F. Cubillos, A. Mahn, and J. Vasques, 'Dehydration of agro products in a hybrid solar dryer controlled through a fuzzy logic system', Int. J. Mod. Nonlinear Theory and Appl., vol. 3, pp. 66-70, 2014.

[27] E. Yani and S. Fajrin, 'Characteristics of coffee bean drying based on flow velocity variation at solar dryer', Teknika, vol. 12, no. 1, pp. 17-22, 2013. (in Indonesian)

[28] S. Widyotomo, 'Performance of a big scale greenhouse for coffee drying process', Pelita Perkebunan, vol. 30, no. 3, pp. 240-257, 2014. (in Indonesian)

[29] H. Syah, R. Agustina, and R. Moulana, 'Design of bin type solar dryer for coffee', Rona Teknik Pertanian, vol. 9, no. 1, pp. 25-39, 2016. (in Indonesian)

[30] R. Agustina, H. Syah, and R. Moulana, 'Characteristic coffee bean drying utilizing bin dryer with heat of rice husk furnace and solar collector', Agrotechno, vol.1 no.1, pp. 20-27, 2016. (in Indonesia). 